Acta vet. scand. 1976, 17, 32-42.

From The State Veterinary Serum Laboratory, Copenhagen, Denmark.

\title{
A MICROBIOLOGICAL STUDY OF PNEUMONIC CALF LUNGS
}

\author{
By \\ V. Bitsch, N. F. Friis and H. V. Krogh
}

\begin{abstract}
BITSCH, V., N. F. FRIIS and H. V. KROGH: A microbiological study of pneumonic calf lungs. Acta vet. scand. 1976, 17, 32-42. Fifty pneumonic calf lungs were subjected to microbiologic screening with regard to bacteria, mycoplasmas, and viruses.

Of bacteria the species most commonly found were Pasteurella multocida (eight lungs), Pasteurella hemolytica (eight lungs), and Corynebacterium pyogenes (13 lungs). Of special interest was the demonstration of Neisseria spp. in five lungs. Mycoplasma dispar was found in 31 lungs, Mycoplasma bovirhinis in 16 lungs, and Ureaplasma in 26 lungs. Cytopathogenic agents were demonstrated in 14 lungs. Four isolates were found to be bovine respiratory syncytial virus, three were bovine viral diarrhea virus, and two were bovine parainfluenza 3 virus. The remaining five cytopathogenic agents were not identified.
\end{abstract}

calf pneumonia; bovine respiratory bateria;

bovine respiratory mycoplasmas; bovine respiratory viruses.

In Denmark, as in other countries, infectious diseases of the respiratory tract of calves are a serious problem.

The etiology of the disease complex is not as yet clearly understooid, but from studies of the microflora of the diseased respiratory tract it would appear that a diversity of microorganisms comprising bacteria, viruses, mycoplasmas, fungi, and chlamydiae may be involved (Omar 1966, Gourlay et al. 1970, Ide 1970, Lillie 1974).

The present examination of a number of pneumonic calf lungs was undertaken primarily to see what results could be brought to light by bacteriological, mycoplasmological, and virological procedures. 


\section{MATERIAL AND METHODS}

Pneumonic calf lungs were obtained from the material received at the Laboratory for routine diagnostic purposes within the period December 1974 to February 1975. During this period material was received from 147 calves with pneumonic changes. After exclusion of cases with chronic apostematous changes, 50 cases representing 46 herds were chosen at random among calves under one year.

\section{Bacteriological examination}

Lung material was inoculated onto $5 \%$ calf-blood agar, $5 \%$ blood agar with polymyxin, $5 \%$ horse-serum agar with $1 \%$ glucose, and Drigalski agar, and incubated aerobically at $37 \mathrm{C}$ for 48 hrs. Lungs suspect of Fusiformis necrophorus infection were further inoculated onto VL-agar with $10 \%$ horse blood and incubated anaerobically. The bacteriological diagnosis was based on cultural and biochemical features as well as on morphology and staining reactions.

Appearance of a few colonies of known non-pathogenic bacteria was considered insignificant and not recorded.

\section{Mycoplasmological examination}

Media. The media used were selected in accordance with the growth requirements of known bovine mycoplasmas.

M y c op la s m a dis par. A medium originally intended for cultivation of Mycoplasma suipneumoniae was used, but with $20 \%$ calf serum instead of horse and swine serum (Friis 1975a). Furthermore, $0.15 \mathrm{mg} / \mathrm{ml}$ of the antibiotic cycloserine was used in addition to bacitracin and meticillin.

U r e a p l a s m a. The above medium, but with $20 \%$ horse serum and $0.05 \%$ urea, was used. The $\mathrm{pH}$ was adjusted at 6.75.

$\mathrm{O}$ ther s pecies. Two modifications of Hayflick's type of medium were employed: one with the $\mathrm{pH}$ adjusted at 7.5, and another enriched with arginine and mucin and with the $\mathrm{pH}$ adjusted at 7.2, intended especially for arginine metabolising species (Friis 1975b). Both modifications involved the use of $20 \%$ horse serum and $0.15 \mathrm{mg} / \mathrm{ml}$ of cycloserine.

Solid media were prepared with Agar-Agar (Oxoid), $0.8 \%$, with incorporation of DEAE-Dextran (Friis 1975b). 
Cultivation and identification procedures. Ten \% suspensions of lung tissue in mycoplasma liquid medium without antibiotics were prepared and dilutions hereof to $10^{-6}$ cultivated in each of the four liquid media. The suspensions were stored at $-25 \mathrm{C}$. The cultures were observed during a period of two weeks, colorshifit of the pH-indicator (phenol red) being taken as indication of growth. After four days of incubation cultures without colorshift were subcultured blindly on solid medium. In case of growth of mycoplasmas these were subcultured in liquid medium, passed through a $0.45 \mu \mathrm{m}$ filter, and cloned once on solid medium. Ureaplasma in mixed cultures were purified by subcultivation of serial tenfold dilutions (to $.10^{-8}$ ) in liquid medium with $\mathrm{pH} 6.0$. Isolates of the genus Mycoplasma were identified by conventional growth inhibition test on solid medium. Rabbit hyperimmune antisera against Mycoplasma dispar, NCTC 10125, and Mycoplasma bovirhinis, NCTC 10118, were used. Ureaplasmas were identified by their ability to degrade urea, by their dependency on serum for growth in liquid medium, and finally by their typical colonies on solid medium which were stainable with $\mathrm{MnCl}_{2}+$ urea (Shepard 1973).

\section{Virological examination}

Tissue cultures and media. Primary calf kidney cell cultures (CK) and the 22nd to 29th passage of a bovine turbinate cell line (BT) (NADC, Ames, Iowa) were used. Maintenance medium for CK cells was Earle solution with $0.5 \%$ lactalbumin hydrolysate and $0.01 \%$ yeast extract, while Eagle minimal cssential medium was used for BT cells. Both media contained $0.1 \mathrm{mg}$ streptomycin, $100 \mathrm{i} . u$. of penicillin, and $100 \mathrm{i} . u$. of nystatin per $\mathrm{ml}$ in addition to $2 \%$ horse or SPF calf serum.

Virological examination. Two CK cell cultures and two BT cell cultures in roller tubes were used for each lung for primary examination. Tubes were inoculated with $0.2 \mathrm{ml}$ of the same lung tissue suspensions as used for the mycoplasma examination, and all lungs were examined at the same time. The tubes were read daily. Per sample, one CK tube and one BT tube were pasisaged onto similar cells if no CPE appeared within nine days. If in this second passage no CPE was seen within 14 days, the examination was recorded as negative.

All lung suspensions producing CPE were titrated by a tenfold dilution procedure with inoculation of two cell cultures per 
dilution. CK cells were used in the cases of Lungs 21, 38, and 39 while BT cells were used for the rest of the isolates.

Identification of isolates. Bovine virus diarrhea (BVD) virus, bovine parainfluenza 3 (PI 3 ) virus, and bovine respiratory syncytial (BRS) virus isolates were identified by neutralization tests with specific rabbit antisera with preimmune sera as controls. The viruses used for immunization were a Danish BVD laboratory strain (VK549/72), the PI 3 reference strain SF4, and a Danish BRS laboratory strain (VK49/73).

\section{RESULTS}

Details of microorganisms isolated are given in Table 1. Pasteurella multocida and Pasteurella hemolytica were isolated each from eight lungs $(16 \%)$. Corynebacterium pyogenes was isolated from 13 lungs (26\%), and Neisseria from five lungs $(10 \%)$. Escherichia coli was isolated in significant numbers from nine lungs (18\%). Fusiformis necrophorus and hemolytic streptococci were isolated each from one lung. A number of different bacteria of doubtful significance were isolated from nine lungs, and in 14 cases no bacteria were isolated.

One or more species of mycoplasma were recovered from 44 lungs $(88 \%)$. M. dispar was found most commonly, namely in 31 cases $(62 \%)$. For M. bovirhinis and Ureaplasma the corresponding figures were $16(32 \%)$ and 26 (52\%), respectively. No other species of mycoplasma was demonstrated. From the table it appears that calves were often found infected already from about two weeks of age.

A cytopathogenic agent was demonstrated in 14 lungs (28\%). Four isolates were identified as BRS virus, multiplying in both CK and BT cells. In some CK tubes presence of the virus could be recognized only by subsequent transfer to BT cells, in which a pronounced and very characteristic CPE was produced. Three isolates were BVD virus*, giving fast and distinct CPE in both cell types. There were two isolates of PI 3 virus, which both grew well on CK cells, while one of them - found at a relatively low titer (Lung 21) - could not be recognized in the BT cells.

These well-known agents isolated from nine lungs (18\% of the lungs) were neutralized by the respective rabbit immune sera with neutralization indices of $\geqq 10^{3}$ to $10^{6}$.

* In all three cases BVD infection had been diagnosed by Dr. A. Meyling in a routine examination by direct immunofluorescence. 
V. Bitsch et al.

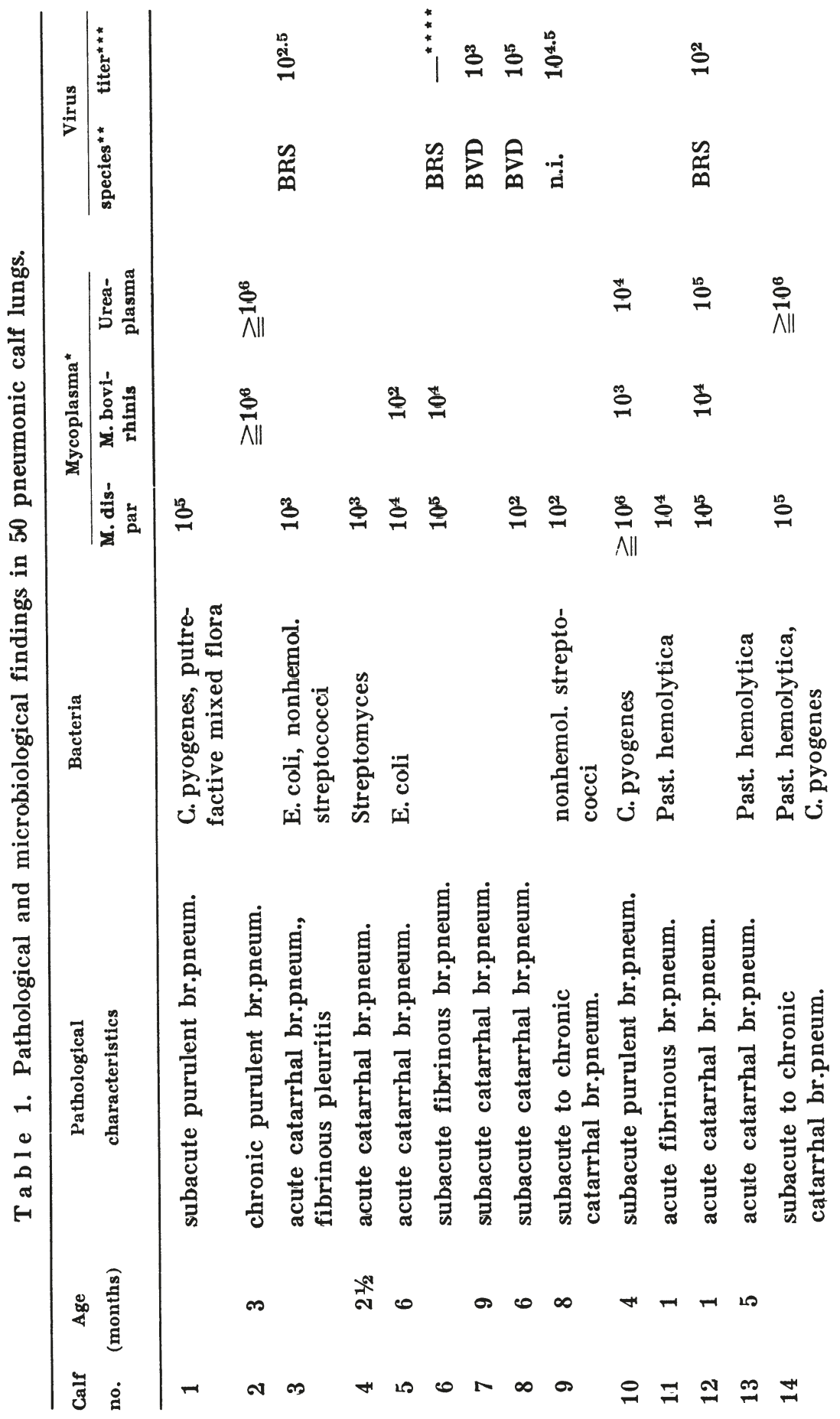




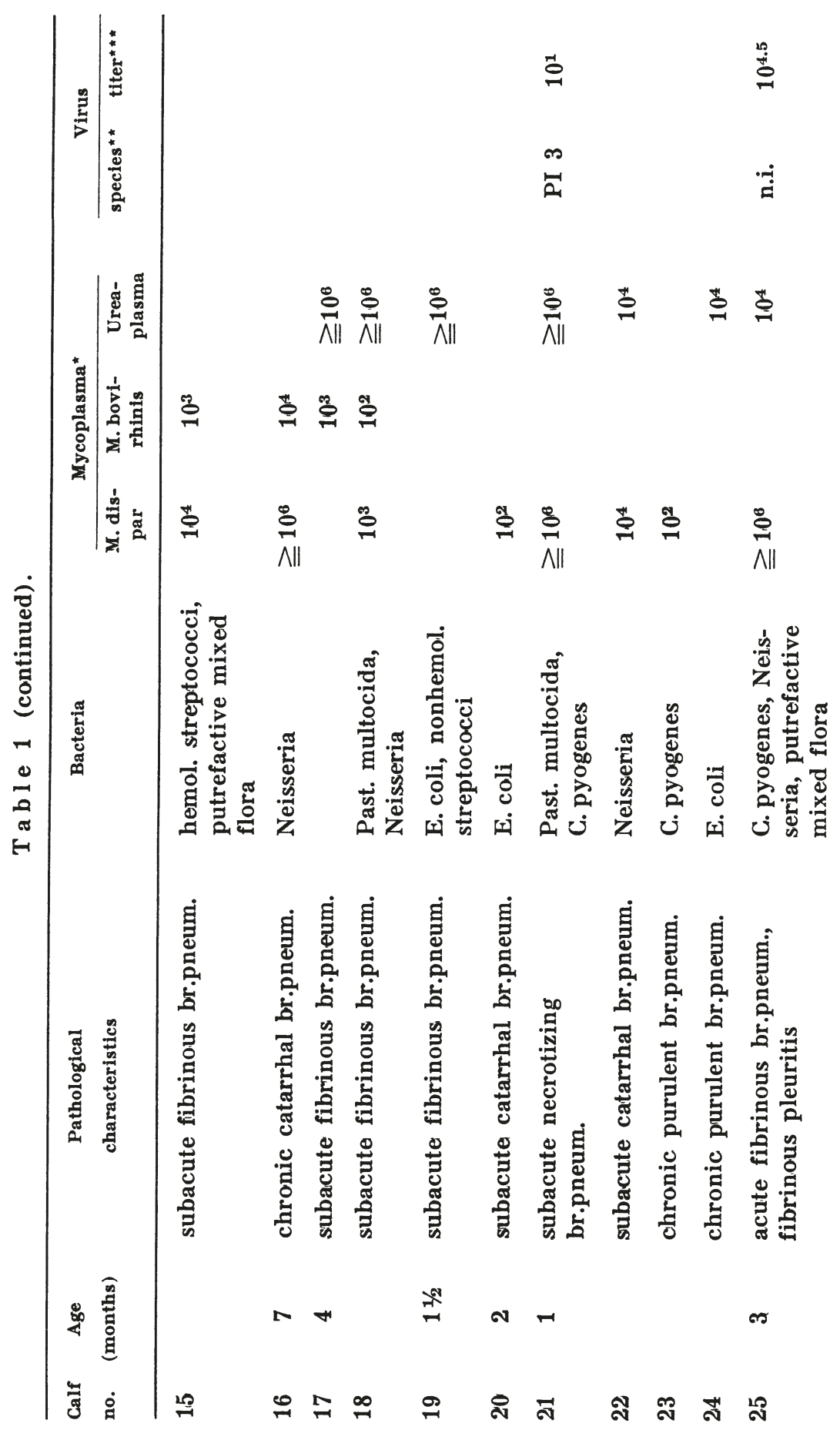




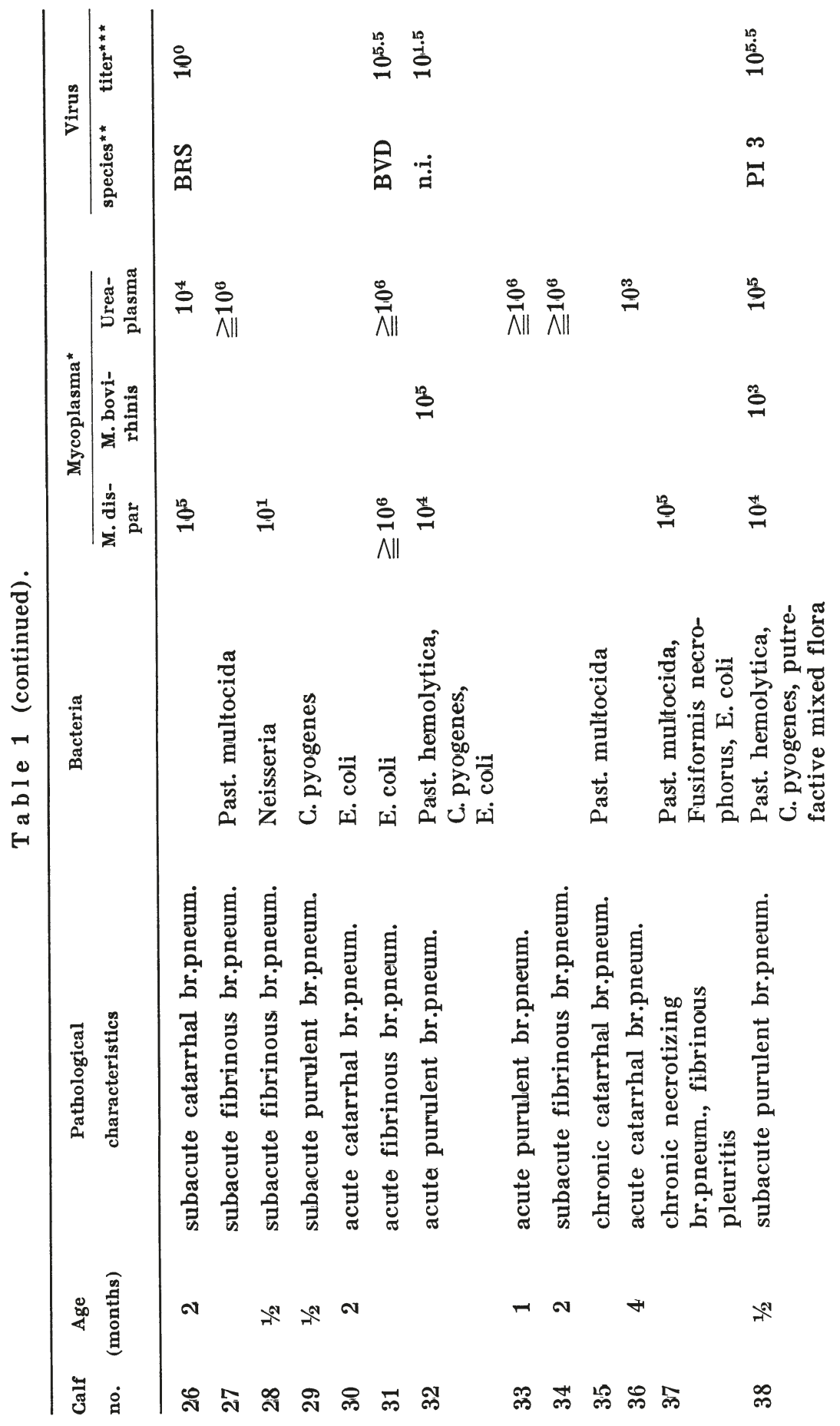




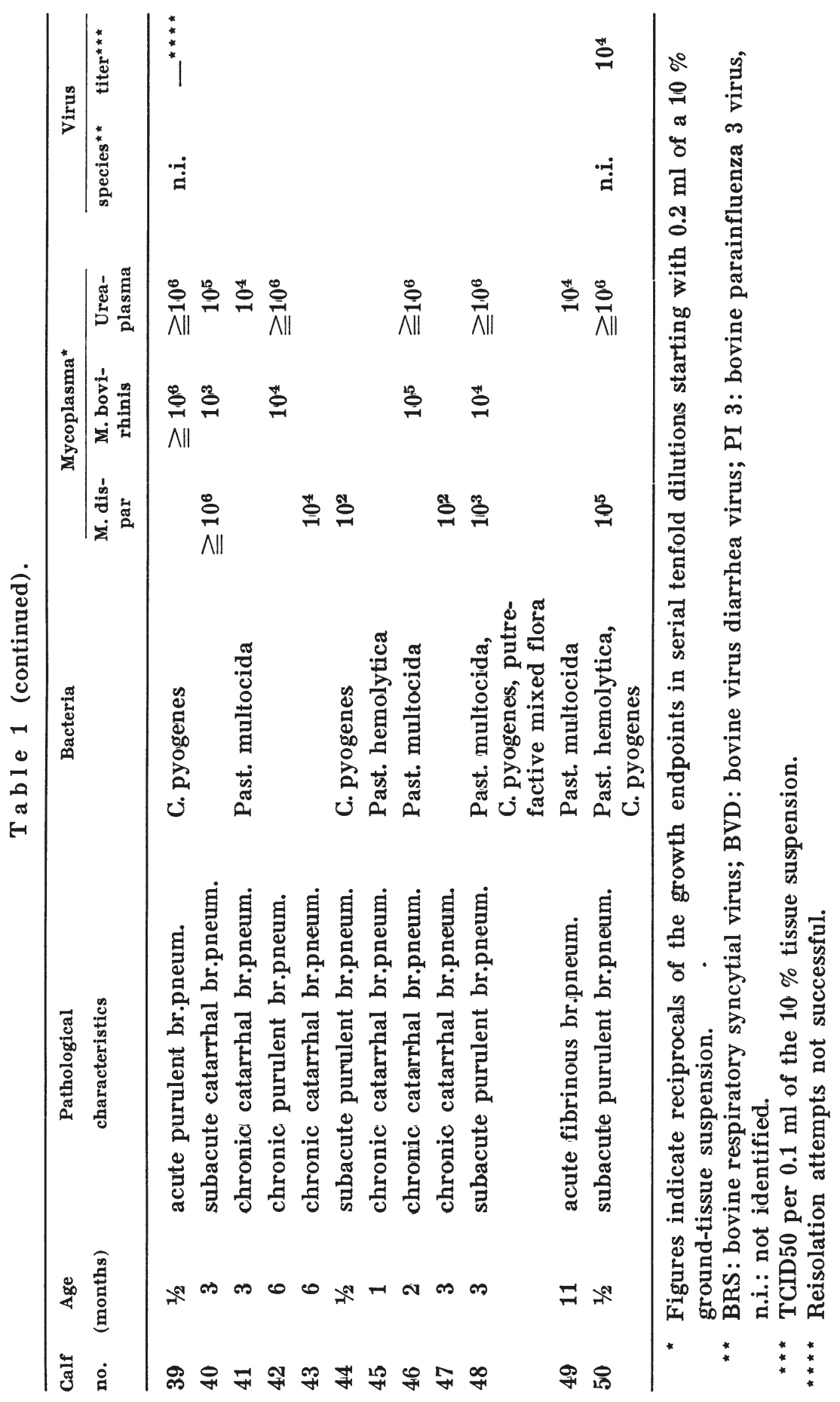


The remaining five agents were less easy to handle. Four of them produced CPE in BT cells only, the fifth (Lung 39) in CK cells only, and then at very low titers. Preliminary identification tests indicated that the isolates from Lungs 9, 25, 32, and 50 were sensitive to ether and insensitive to 5-Iodo-2-deoxyuridine ( $50 \mu \mathrm{g} / \mathrm{ml}$ ), while the isolate from Lung 39 was found insensitive to both treatments. All of the five agents could be passed through $0.1 \mu \mathrm{m}$ Gelman filters (Metricel, GA-9) and growth was not inhibited by tetracycline ( $25 \mu \mathrm{g}$ tetracycline chloride per $\mathrm{ml}$ ).

Titration of lung suspensions were performed on BT cells, except for Lungs 21, 38, and 39, which were titrated on CK cells. To facilitate reading of the BRS titrations, a second passage of inoculated BT cultures was made.

\section{DISCUSSION}

Acconding to case histories many of the calves examined had been treated with antibiotics, which may account for the fact that no bacteria were found in $28 \%$ of the cases. The isolates resulting from the examination belong to species of bacteria commonly occurring in pneumonia in calves (Omar 1966). It is noteworthy, though, that Neisseria, which was first demonstrated in calf lungs by Hunter \& Harbourne (1964), was found in five cases.

The examination for mycoplasmas resulted in the recovery of M. dispar, M. bovirhinis, and Ureaplasma from, respectively, 62, 32 , and $52 \%$ of the pneumonic lungs. This result is in agreement with the work of Gourlay et al. (1970) who also found the abovementioned mycoplasmas, and those only, by cultivation from 65 pneumonic calf lungs. As regards frequency of isolation, however, the two materials are not readily comparable, because the material of Gourlay et al. was divided in subclinical and fatal cases.

In the present work the recovery of M. dispar was accomplished in a medium different from that used by Gourlay et al., but both media were originally designed for primary isolation of Mycoplasma suipneumoniae. Andrews et al. (1973) reported that M. dispar was sensitive to penicillin-G, a feature shared by M. suipneumoniae (Friis 1971). It had been noted also in studies preliminary to the present work, giving reason to other antibiotics being chosen as bacteriostatics. 
Of well-known bovine viruses, BRS virus was found most frequently, namely in four lungs. This seems in accordance with findings by Wellemans \& Leunen (1975) who, on the basis of comprehensive serological examinations of outhreaks of enzootic respiratory distress, concluded that BRS virus was the virus most frequently involved. It should be noted that in an examination of 65 pneumonic calf lungs Gourlay et al. were unsuccessful in isolating viruses.

None of the nine virus isolates originated from lungs with chronic pathologic changes, and the same applies to the five unidentified cytopathogenic agents. Thus, cytopathogenic agents were demonstrated in $37 \%$ of acute and subacute cases.

\section{REFERENCES}

Andrews, B. E., R. H. Leach, R. N. Gourlay \& C. J. Howard: Enhanced isolation of Mycoplasma dispar by substitution of ampicillin for benzylpenicillin in growth media. Vet. Rec. 1973, 93, 603.

Friis, N. F.: Sensitivity of Mycoplasma suipneumoniae to penicillin-G. Acta vet. scand. $1971,12,120-121$.

Friis, $N$. F.: Some recommendations concerning primary isolation of Mycoplasma suipneumoniae and Mycoplasma flocculare. Nord. Vet.-Med. 1975a, 27, 337-339.

Friis, N. F.: The SPS and digitonin tests applied to porcine mycoplasmas. Acta vet. scand. 1975b, 16, 474-476.

Gourlay, R. N., A. Mackenzie \& J. E. Cooper: Studies of the microbiology and pathology of pneumonic lungs of calves. J. comp. Path. 1970, 80, 575-584.

Hunter, D. \& J. F. Harbourne: The isolation of Neisseria catarrhalis from pneumonic bovine lungs. Vet. Rec. 1964, 76, 738.

Ide, P. R.: The etiology of enzootic pneumonia of calves. Canad. vet. J. 1970, 11, 194-202.

Lillie, L. E.: The bovine respiratory disease complex. Canad. vet. J. 1974, 15, 233-242.

Omar, A. R.: The aetiology and pathology of pneumonia in calves. Vet. Bull. 1966, 36, 1-15.

Shepard, M. C.: Differential methods for identification of T-mycoplasmas based on demonstration of urease. J. infect. Dis. 1973, 127, S22-S25.

Wellemans, G. \& J. Leunen: Le virus respiratoire syncytial et les troubles respiratoires des bovins. (Bovine respiratory syncytial virus in bovine enzootic pneumonia). Ann. Méd. vét. 1975, 119, $359-369$. 


\section{SAMMENDRAG}

En mikrobiologisk unders $\phi$ gelse af pneumoniske kalvelunger.

50 pneumoniske kalvelunger er blevet unders $\emptyset$ gt med henblik på forekomst af bakterier, mykoplasmer og virus.

Blandt bakterier var de hyppigst forekommende følgende: Pasteurella multocida i 8 lunger, Pasteurella hæmolytica i 8 lunger og Corynebacterium pyogenes i 13 lunger. Af speciel interesse var påvisningen af Neisseria spp. i 5 lunger. De påviste mycoplasmer var Mycoplasma dispar i 31 lunger, Mycoplasma bovirhinis i 16 lunger og Ureaplasma i 26 lunger. Cytopatogene agentia blev påvist i 14 lunger. Fire isolater fandtes at være bovint respiratorisk syncytielt virus, 3 var bovint virus diarrhoe virus og 2 var bovint parainfluenza-3-virus. $\emptyset$ vrige 5 cytopatogene agentia blev ikke identificeret.

(Received January 19, 1976).

Reprints may be requested from: The State Veterinary Serum Laboratory, Bülowsvej 27, DK-1870 Copenhagen V, Denmark. 